\title{
Eurasian Kurgan Database - a citizen science tool for conserving grasslands on historical sites
}

\author{
Balázs Deák ${ }^{1(0)}$, Csaba Albert Tóth ${ }^{2}$ (i) Ádám Bede $^{3}$ (i) , Iva Apostolova ${ }^{4}$ (i) , \\ Tatyana M. Bragina ${ }^{5,6}$ (1) , Ferenc Báthori ${ }^{7,8}$ (i) \& Miklós Bán ${ }^{8,9}$ (1)
}

Key words: biodiversity, burial mound (= kurgan), cultural heritage, dry grassland, habitat-island, historical heritage, steppe.

Ključne besede: biodiverziteta, gomila (= kurgan), kulturna dediščina, suha travišča, habitatni otok, zgodovinska dediščina, stepa.
Received: 15. 03. 2019

Revision received: 28. 05. 2019

Accepted: 29. 05. 2019

\section{Co-ordinating Editor:}

Rocco Labadessa

\begin{abstract}
Eurasian steppes have an essential role in conserving biodiversity, but due to the huge habitat loss in the past centuries they are often preserved only in small refuges. Among such refuges are the ancient steppic burial mounds (the so called 'kurgans') which have a high cultural and historical importance and are also essential sites of nature conservation. Despite their high number (approximately half million) and conservational importance there is a huge lack of knowledge on the locality and conservational state of the kurgans in most regions of Eurasia. To fill this knowledge gap, we built a public database which allows to record and query basic information on their cultural values and factors (such as land cover type, threatening factors, cover of woody species) that might serve as a basis for their effective conservation. The database provides a transparent, public and easy-to-use source for conservation managers and landscape planners focussed on grassland conservation. In addition, it also provides background information for other associate disciplines and public agencies dealing with the protection of cultural heritage.
\end{abstract}
Izvleček
Evrazijske stepe imajo pomembno vlogo pri ohranjanju biotske raznovrstnosti, vendar so zaradi velike izgube habitatov v zadnjih stoletjih ohranjene le na majh- nih območjih. Med takimi refugiji (zatočišči) so starodavne stepske gomile (tako imenovani 'kurgani'), ki imajo po eni strani pomembno kulturno in zgodovinsko vrednost, po drugi strani pa predstavljajo pomembna naravovarstvena območja. Kljub njihovi številčnosti (približno pol milijona) in naravovarstvenemu pomenu je poznavanje o razširjenosti in naravovarstvenemu stanju gomil na večini območij Evroazije pomanjkljivo. Zato smo naredili javno podatkovno bazo, v kateri lahko zbiramo in iščemo osnovne podatke o kulturni vrednosti in dejavnikih (kot na primer raba tal, dejavniki ogrožanja, pokrovnost lesnatih vrst), ki služijo kot osnova za njihovo uspešno varovanje. Podatkovna baza je vir, ki je transparenten, javen in enostaven za uporabo, in ga uporabljajo naravovarstveniki in načrtovalci s posebnim ozirom na ohranjanje travišč. Dodatno pa predstavlja tudi informacije za druge vede in javne agencije, ki se ukvarjajo s kulturno dediščino.

MTA-DE Biodiversity and Ecosystem Services Research Group, Egyetem sqr. 1, Debrecen 4032, Hungary. E-mail: debalazs@gmail.com

Department of Physical Geography and Geoinformation Systems, University of Debrecen, Egyetem sqr. 1, Debrecen 4032, Hungary.

University of Szeged, Department of Geology and Paleontology, Egyetem str. 2-6, Szeged 6722, Hungary.

Institute of Biodiversity and Ecosystem Research, Bulgarian Academy of Sciences, Sofia, 1113, Bulgaria.

Kostanay State Pedagogical University named after Omirzak Sultangazin, Kazakhstan, Tauelsizdik Street 118, Kostanay, 110000, Kazakhstan.

6 Azov-Black Sea Branch of the FSBSI “VNIRO” (“AzNIIRKH”), Beregovaya Street, 21v, Rostov-on-Don 344002, Russia.

7 Department of Ecology, University of Debrecen, Egyetem sqr. 1, Debrecen 4032, Hungary.

8 Department of Evolutionary Zoology and Human Biology, University of Debrecen, Egyetem sqr. 1, Debrecen 4032, Hungary.

9 MTA-DE Behavioral Ecology Research Group, Department of Evolutionary Zoology and Human Biology, University of Debrecen, Debrecen, Hungary. 


\section{Introduction}

Dry grasslands of the World have an essential conservational role, as they harbour a considerable proportion of biodiversity and provide habitat for several species confined to open habitats (Squires et al. 2018). The most extended stands of dry grasslands are in the steppe and forest-steppe biomes of Eurasia (Erdős et al. 2019, Valkó et al. 2016, 2018a). Steppic grasslands due to their special habitat conditions and long-term traditional management represent a unique conservation value. However, due to the agricultural intensification and expansion of urban areas and the associated infrastructure, the formerly existing continuous grasslands have been fragmented in many regions due to the agricultural intensification and expansion of urban areas and the associated infrastructure (Biró et al. 2018, Elias et al. 2018, Sopotlieva et al. 2018, Szabó \& Ruprecht 2018). In transformed landscapes located in the regions in the western part of the steppe and forest steppe biomes - fragments of steppic grasslands are present in small habitat islands harbouring the remnants of the former vegetation (Deák et al. 2018).

Sites with cultural, historical or sacred importance are often associated with outstanding nature conservation values and biodiversity (Bhagwat \& Rutte 2006, Vershuuren et al. 2010, Molnár et al. 2017, 2018, Löki et al. 2019a,b). These sites often harbour the last remnants of the natural habitats and their species pool even in highly transformed landscapes. Due to the presence of social respect and taboos these sites are used in an extensive way and less affected by human disturbances than other areas (Frascaroli et al. 2016). Conservation role of historical and sacred sites is getting to be more recognised nowadays, when a considerable amount of natural habitats has been transformed into agricultural fields or urban areas (Stockstad 2010). The special importance of these sites is that by harbouring a considerable proportion of biodiversity they extend the borders of the few protected areas in intensively used landscapes (Bhagwat \& Rutte 2006).

The ancient burial mounds (so called 'kurgans') are the most widespread historical sites of the Eurasian steppes. They represent essential historical, cultural, spiritual and conservational values (Deák et al. 2016a). The kurgans (named also as barrows, mounds, tumuli, movile and mogili) were emerged for burial purposes from the Eneolithic, Bronze and Iron Ages (IV-I. millennia BC) to the Migration Period and Medieval Ages (I-II. millennia AD) by steppic cultures such as Yamnayas, Kimmerians, Scythians, Sarmatians, Thracians, Hungarians, Cumanians and other Turkish tribes (Gimbutas 2000, Rowińska et al. 2010, Szilágyi et al. 2013, Demkin et al. 2014, Sudnik-Wójcikowska \& Moysiyenko 2014). Most of the mounds were constructed by piling fertile soil layers of the neighbouring areas upon the pit grave of an important person (Lisetskii et al. 2016a). By doing so, steppic people emerged well visible historical sites, which have been serving as iconic landscape elements of the extended open steppic landscapes since millennia. In the later ages the kurgans were often used for secondary burial rites also by the non-mound-builder cultures. The height of the kurgans typically ranges between half to a few metres, even in some cases they can reach 15-20 metres just like the Oguz kurgan in Ukraine (Deák et al. 2016a, Dembicz et al. 2016). The diameter of the kurgans shows a high variability; the smallest ones are only a few metres in diameter, whilst the size of the largest ones can be even above 100 metres. The kurgans are widespread in the whole steppe biome, and in a considerable part of the forest-steppe biome (Sudnik-Wójcikowska et al. 2011, Lisetskii et al. 2016b, Deák et al. 2017). Their westernmost occurrence is in Hungary, the easternmost kurgans are in Eastern China. Their estimated present number is about 400,000-600,000 (Deák et al. 2016a).

The kurgans are important monuments of our historical heritage, as they are one of the oldest constructions of the human civilisation in the steppe region, which have been preserved till present days, and in many cases they also hold the artefacts connected to the burial rituals (Gimbutas 2000, Bede et al. 2015). Every kurgan should be considered as an archaeological site, even a completely ploughed and disturbed kurgan might hold the original central pit grave. Thus, even the damaged or destroyed mounds are important for the heritage protection and for the official registers and scientific databases. Though the ancient cultures that built the kurgans have been disappeared long time ago, kurgans still hold their sacred functions which is shown by the several mythological and folklore legends, tales, novels and poems about them (Sudnik-Wójcikowska \& Moysiyenko 2014). Stone rings, stelaes and anthropogenic statues were stood on kurgans by the ancient nomadic people in the whole Eurasian steppe (Davis-Kimball et al. 2000, Anthony 2010, Gołębiowska-Tobiasz 2013, Parzinger 2017). In many cases the sacredness of former cultures are interwoven with the new cultures. Christian cultures often used the kurgans for emerging churches, sanctuaries, cemeteries, crosses, statues or other sacred monuments (Figure 1). Lot of kurgans got secondary functions, for example border marks, mapping points or buildings (farms, cellars, canals, roads etc.), especially in the last centuries.

Besides their historical, cultural and sacred importance kurgans also have an important role in conserving biodiversity. In transformed landscapes kurgans harbouring 


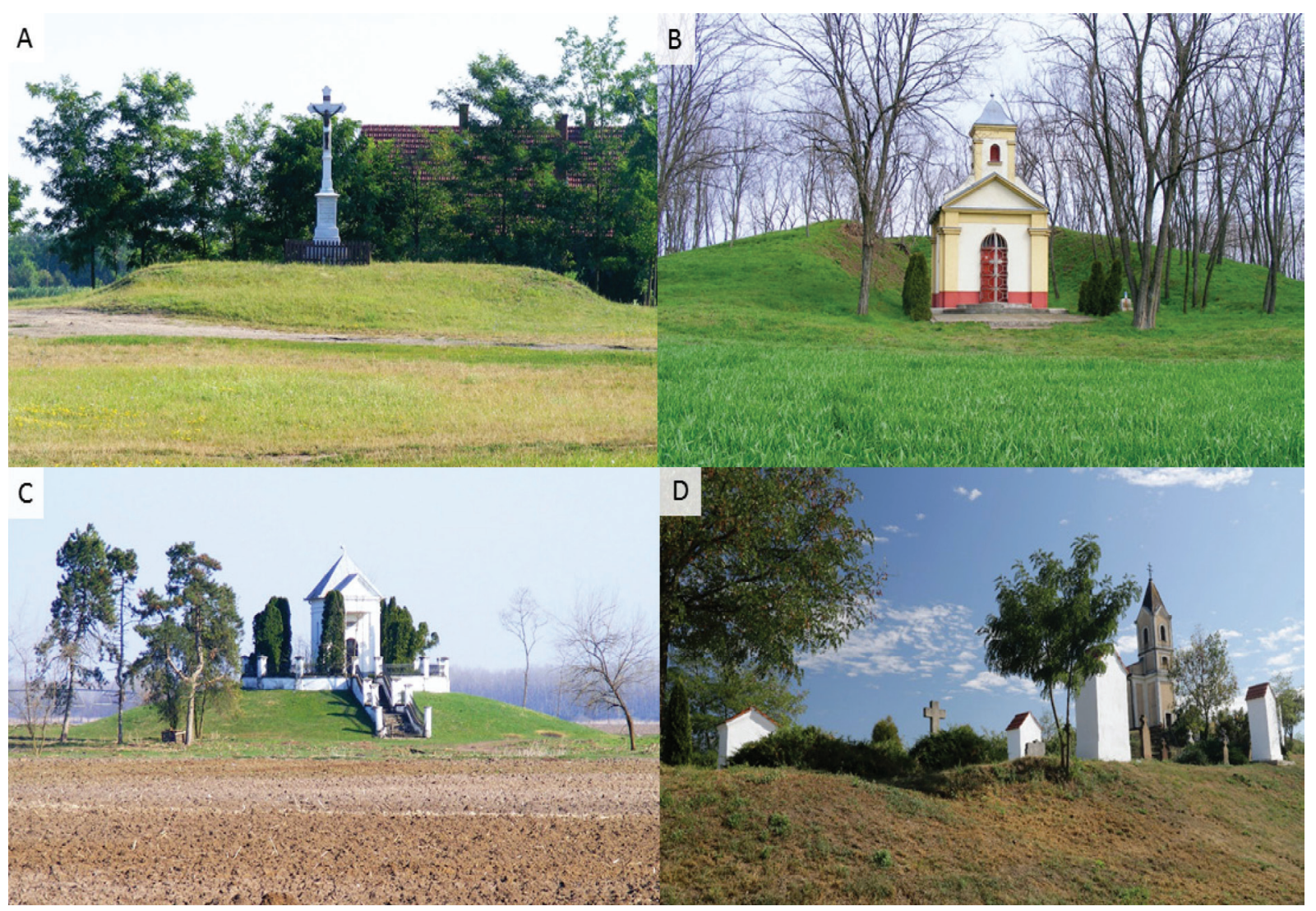

Figure 1: Christian cultural values associated to kurgans covered by grassland vegetation. A - Cross on an anonym kurgan (near to the settlement Szegvár; Hungary); B - Chapel on the Kriptáj-halom kurgan (near to the settlement Dombegyház; Hungary); C - Chapel on the Torda-halom kurgan (near to the settlement Szeghalom; Hungary); D - Stations of the cross on the Kálvária-halom kurgan (Tiszaörs; Hungary). Photos by Ádám Bede (A-C) and Balázs Deák (D).

Slika 1: Krščanske kulturne vrednosti, povezane z gomilami, in prekrite s travniško vegetacijo. A - Križ na neznani gomili (v bližini naselja Szegvár; Madžarska); B - Kapelica na gomili Kriptáj-halom (v bližini naselja Dombegyház; Madžarska); C - Kapelica na gomili Torda-halom (v bližini naselja Szeghalom; Madžarska); D - Postaje križevega pota na gomili Kálvária-halom (Tiszaörs; Madžarska). Fotografije Ádám Bede (A-C) in Balázs Deák (D).

grassland vegetation are essential refuges of the steppic flora and fauna (Wódkiewicz et al. 2016, Deák et al. 2018). Due to the interplay of the respect of local communities and their hill like shape (which is less adequate for ploughing) they could preserve the last remnants of the steppe fragments even in agricultural or urban landscapes (Sudnik-Wójcikowska et al. 2011, Deák et al. 2016b). Several studies demonstrated that in spite their often isolated state, kurgans can harbour an outstandingly high biodiversity, which is often disproportionate to their small size. Based on their survey involving 106 kurgans along a large geographical gradient in Ukraine Sudnik-Wójcikowska et al. (2011) reported the presence of 721 plant species on these historical sites. This high biodiversity conservation potential is really impressing, and if we take into account that 72 of the 721 species were regionally red listed ones (such as Astragalus borysthenicus, A. dasyanthus, A. pallescens, Cerastium ucrainicum, Crocus reticulatus, Dianthus lanceolatus, Elytrigia stipifolia, $G a-$ lium volhynicum and Phlomis hybrida) the conservation potential of the kurgans becomes even more emphasised. In their survey on 168 kurgans in Hungary Deák et al. (2016a, 2018) found 469 species of which there were altogether 73 regionally rare and/or protected grassland species typical to alkali and loess steppes (Anchusa barrelieri, Aster sedifolius, Carduus hamulosus, Chamaecytisus rochelii, Inula germanica, Phlomis tuberosa and Ranunculus illyricus).

This high species richness is supported by the long-term relatively undisturbed status of the kurgans and also by the high environmental heterogeneity provided by their hill shape (Sudnik-Wójcikowska et al. 2011, Deák et al. 2016b). The special habitat conditions provided by the micro-sites harboured by the slopes with different inclination and aspect, and also by the top of the kurgans support the co-existence of several species with different habitat 
preferences (Lisetskii et al. 2016a). Given their extraordinarily high density in some regions with transformed landscapes kurgans can also act as stepping stones contributing to the maintenance of a functioning network of semi-natural grasslands (Szabó et al. 2012, Deák et al. 2016a). Even though till the recent past kurgans were mostly appreciated because of their refuge role in transformed landscapes of Western Eurasia, there is a scientific evidence for that they also have an important conservational role in the more intact Central-Asian steppes. In their study of Kazakh kurgans Deák et al. (2017) proved that even small (1-1.5 m high) kurgans can act as biodiversity hotspots in the pristine steppes and can considerably improve the landscape-scale diversity of grassland specialist plants. The reason for this is again originated from the high diversity of the micro-sites located on the kurgans, which supports a high species density and also the presence of some indicator species which are generally not present in the neighbouring landscape and are mostly confined to the kurgans (Figure 2).

In spite of their high conservational and cultural importance kurgans are facing several factors threatening their existence or causing the degradation of their grassland habitats. The most serious anthropogenic threats are the urbanisation, agricultural utilisation (especially ploughing), soil extraction, treasure hunting, archaeological research, overgrazing and the cessation or lack of the management (Sudnik-Wójcikowska \& Moysiyenko 2014, Deák et al. 2016a). Because of these disturbances litter accumulation, encroachment of woody and weed
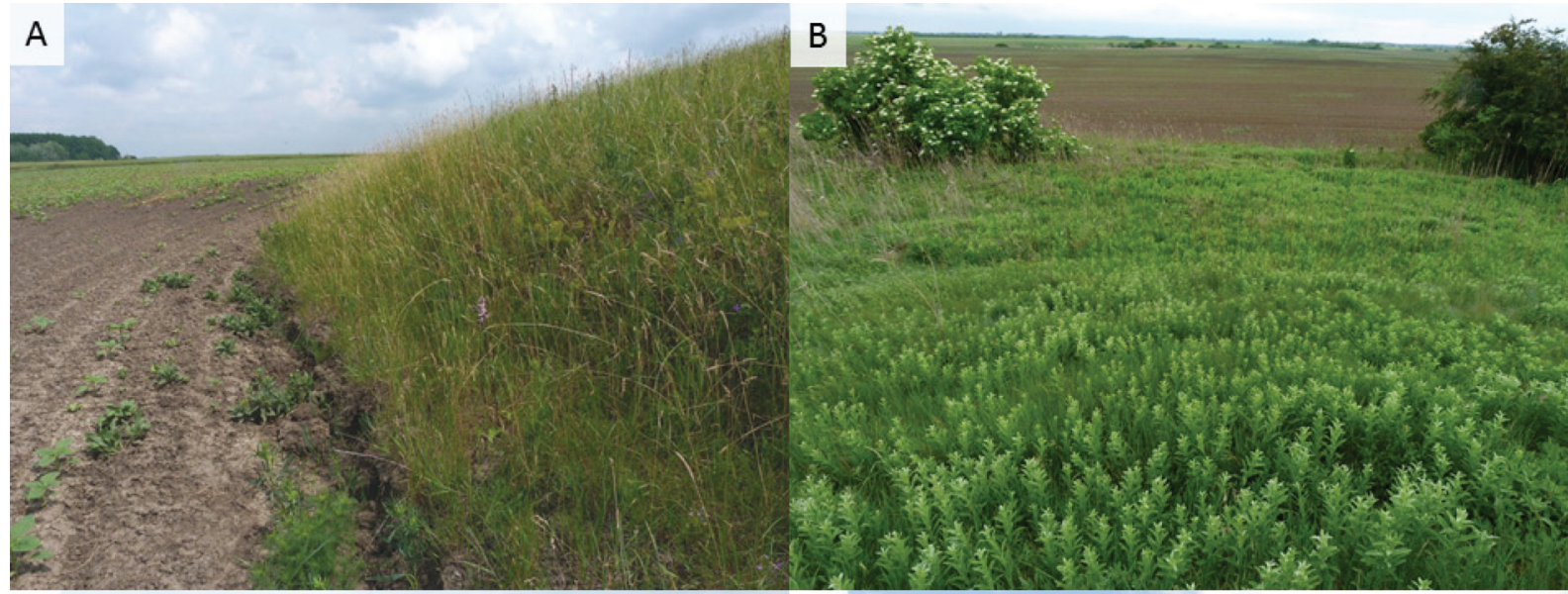

C

D
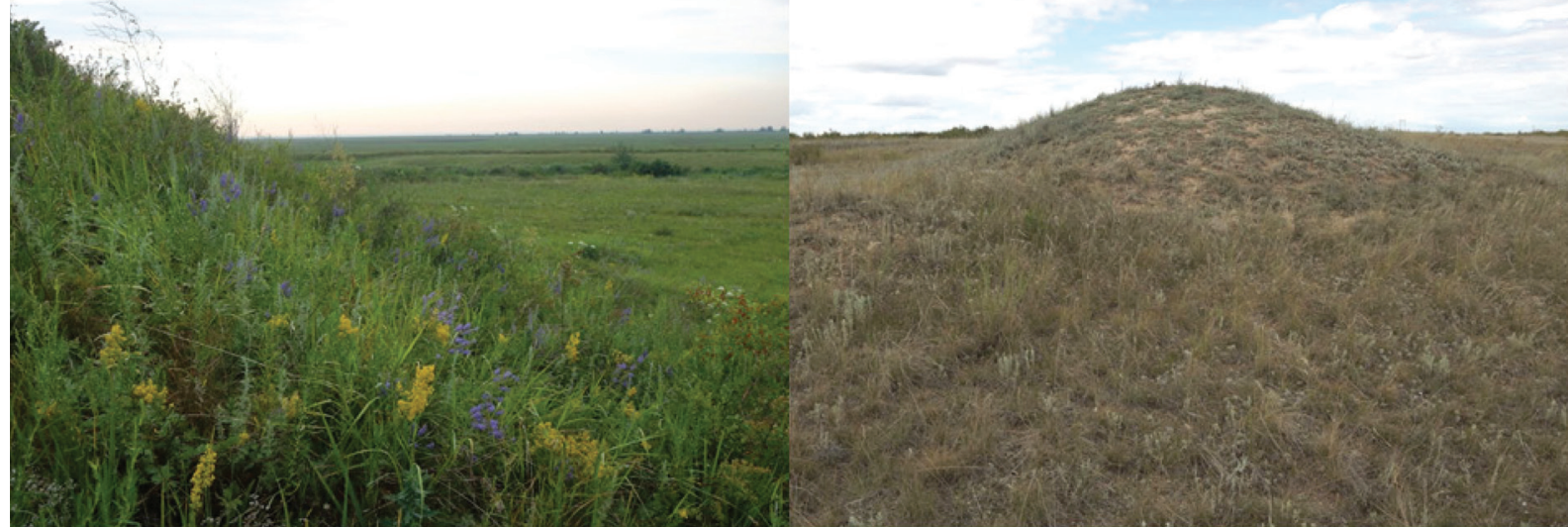

Figure 2: Kurgans harbouring grassland habitats. A - Loess grassland on Sólyom-halom kurgan, which is surrounded by extended arable lands (near to the settlement Tiszacsege; Hungary); B - Thousands of the red listed Inula germanica on the isolated Mondró-halom kurgan (near to the settlement Hencida; Hungary); C - Anonym kurgan harbouring steppe vegetation (near to Kostanay; Kazakhstan); D - Anonym kurgan surrounded by steppe vegetation (near to Aktobe; Kazakhstan). Photos by Balázs Deák.

Slika 2: Gomile s travniškimi habitati. A - Travniki na lesu na gomili Sólyom-halom, ki jo obkrožajo obdelana polja (v bližini naselja Tiszacsege; Madžarska); B - Tisoči primerkov vrste z rdečega seznama Inula germanica na izolirani gomili Mondró-halom (v bližini naselja Hencida; Madžarska); C - Neznana gomila s stepsko vegetacijo (v bližini naselja Kostanay; Kazahstan); D - Neznana gomila, obdana s stepsko vegetacijo (v bližini naselja Aktobe; Kazahstan). Fotografije Balázs Deák. 
species and the invasion of alien species are also typical on kurgans leading to a gradual loss of grassland biodiversity (Deák et al. 2018). Conservation actions on kurgans still harbouring grassland habitats are often inevitable for preserving these grasslands. However, focused management of the kurgans is often challenging due to their small size and dispersed locations, which requires extra efforts and resources from the conservation managers. This problem can be partly solved by involving local communities and NGOs into management actions. As shown by the case study of Valkó et al. (2018b) those attributes which often makes kurgans a subordinate target for large-scale management plans allows the effective participation of small voluntary communities. The kurgans which are generally of a size less than 0.3 hectares are proper objects for volunteers aiming to conserve or restore a small, but significant part of their local historical, cultural and natural heritage.

\section{Aims and motivation for establishing an up-to-date Eurasian kurgan database}

Both for large-scale management plans and actions of local activists some essential basic information would be needed which determine the necessary actions for their conservation: the location of the kurgans and information about their current conservation state. Even though kurgan databases exist in almost all countries holding kurgans, these databases are often incomplete and focus only on large iconic kurgans (Deák et al. 2016a). They generally provide data only on the location of the kurgans, represent only a limited area and are not available for the public (e.g. for NGOs, researchers or even for conservation agencies). Thus, there is an urgent need for a widely available, up-to-date kurgan inventory including factors that might serve as a basis for their effective conservation. Potential resources of such data are from scientific studies on kurgans and from local citizens.

Fortunately in recent years the number of studies focusing on the vegetation and ecology of the kurgans shows a continuously increasing trend (Rowińska et al. 2010, Pető \& Barczi 2011, Sudnik-Wójcikowska et al. 2011, Lisetskii et al. 2014, 2016a,b, Moysiyenko et al. 2014, Sudnik-Wójcikowska \& Moysiyenko 2014, Tóth et al. 2014, 2018, Bede et al. 2015, Deák et al. 2016a,b, 2017, 2018, Dembicz et al. 2016, 2018, Wódkiewicz et al. 2016, Godó et al. 2018, Valkó et al. 2018b). In most cases for supporting conservation actions even some byproduct (such as the presence of invasive species, land use or cover of woody vegetation) of these studies would be informative which does not affect the success of the scientific publication or pose threat of revealing the essential parts of the data collected. To fill the huge knowledge gap regarding the kurgans involvement of local communities also seems to be a vital option. Given the fact that kurgans are interesting historical places they raise the attention of the local population. Even those people who are not definitely engaged in nature conservation, but are interested in history, culture and folklore of their close environment are interested in kurgans (Valkó et al. 2018b). This positive attitude might support the involvement of local populations into data collection.

Citizen science is an increasingly powerful tool in nature conservation management and decision making (Gray et al. 2016). On the one hand, public participation in the monitoring can be an efficient tool in inventorying kurgans which are in the close vicinity of the home range of the participants. On the other hand, the involvement of local citizens in the monitoring can considerably contribute to informing the wide societal audience about the importance of kurgan protection and also can encourage public conservation actions. Kurgans provide a good opportunity for involving citizens in collecting basic data which supports conservation, such as the location, land cover types, presence of threatening factors, cultural buildings, cultural and folkloristic values. These data can be reliably recognised by volunteers without any special training and can also be recorded by the GPS and the camera of a mobile phone. To facilitate this process, we set up a public online database (Eurasian Kurgan Database, Deák 2019) to which both scientists and citizens can upload their observations about the kurgans they visited. Given the fact that kurgans have a wide distribution overarching many countries and a considerable part of Eurasia, we hope that such an initiative can provide essential data from understudied regions and can bring fresh perspectives and critical information for the conservation of the Eurasian kurgans.

\section{Structure of the Eurasian Kurgan Database}

The database (http://openbiomaps.org/projects/kurgan) provides possibility to collect two types of data regarding the kurgans. The two levels differ in the complexity of the data provided. The 'basic data form' can be used for recording data about the name and the geographical position of the kurgans. Data on the position of the kurgans can contribute to our knowledge on the distribution of kurgans in Eurasia, and possibly can reveal new geographical regions from where the presence of the kurgans 
had been not reported before. These coordinates can also serve as a basis for data providers showing areas where more data is needed on the distribution of kurgans. There is a possibility to record more detailed data by the 'complex data form' which involves columns on the physical, biological and cultural attributes of the kurgans and on the factors threatening their existence. The attributes to collect were selected considering that data providers are not necessarily professional biologists or geographers; thus only such data is collected which can be recognised or estimated without any previous professional training. Furthermore, even the database is capable for recording species occurrences this option is not used on the public interface in order to avoid any activities that might harm the grassland habitat preserved on the kurgan (e.g. collection of rare plant or animal species).

The complex data form allows to record the name of the kurgan, the date of the survey and to provide coordinates. Coordinates can be uploaded manually but there is also a possibility to visually record the locality on a vector-based or a raster-based map. Data providers should upload photographs which help to visualise the kurgan, can provide important information on its conservation state and can be useful for quality checking the uploaded data. Collecting data on the land cover typical to the kurgan (for example grassland, arable land, forest, road, orchard etc.) can provide useful information for estimating the potential conservation status of the kurgans, provides an overview on the proportion of intact kurgans and the ones which are considerably influenced by human activities.

To have a comprehensive overview on the factors harming biodiversity there is a possibility to record threatening factors. The factors to record were listed according to the results of the review of Deák et al. (2016a), in which based on the literature and the expertise of kurgan experts the authors evaluated the most problematic threatening factors acting on Eurasian kurgans (such as ploughing, overgrazing, presence of modern buildings, non-prescribed burning, technical sports, overabundant burrowing animals, woody encroachment and presence of weeds and invasive species). Having knowledge on these attributes can be a good basis for setting up a management plan and can be useful for setting up priority action plans in case of limited resources. Data on the level of woody encroachment is one of the most essential data for conservation actions in the forest steppe biome. The reason is whilst grassland species can tolerate a low level $(<10 \%)$ of woody encroachment, they are likely to disappear or at least significantly suppressed under increasing canopy cover (>50\%) (Gazol et al. 2012). In order to optimise the costs of the management conservation actions should focus on kurgans with a woody cover not more than $10-50 \%$ as on these kurgans grassland vegetation can be effectively restored by shrub cutting or cutting the trees using moderate amount of resources.

As historical and cultural values and sacred functions are inseparable from the existence of the kurgans, besides the attributes related to conservation, the database provides possibility to record the presence of sacred and cultural buildings (such as statues, crosses, headboards, ancient ruins, sanctuaries, graves, cemeteries, churches etc.) or other important and valuable landscape elements (border marks, ditches, old mapping points etc.); furthermore a short description of cultural value confined to the kurgan.

\section{Feasibility of the database, application possibilities}

Considering the need for a long-term sustainable database (Bastow \& Leonelli 2010), we have chosen a dynamically developed open source database framework (OpenBioMaps: Bán et al. 2014). OpenBioMaps provides interfaces for uploading and accessing data. Our database has been placed on a freely usable, long-term database repository that is shared by several institutions as an OpenBioMaps partner.

The Eurasian Kurgan Database aims to fill an existing information gap by collecting and providing a public repository of basic kurgan data that can be used by a wide range of end-users. The focus of the database is on the conservation status of the kurgans. It provides a transparent and an easy-to-use platform for conservation managers and landscape planners who require baseline information on the location, typical land use type and threatening factors present on the kurgans. As there is a possibility for collecting repeated data records from the same kurgan the database can also be used for monitoring purposes (such as for monitoring the encroachment of woody species or follow the land cover changes on the kurgans; e.g. changes in the proportion of ploughed kurgans). By providing possibility for collecting data on the cultural values of the kurgans it might be useful for people who are not definitely engaged to nature conservation but would like to explore the hotspots of their local cultural and historical heritage. In addition, the database also provides background information for other associate disciplines (e.g. archaeology, landscape archaeology, environmental and landscape history, historical geography) and public agencies (archaeological site register, monument and heritage protection, ecotourism).

The database provides data for informing local communities and conservation managers. For accessing full 
comprehensive data a registration is needed; however the database provides a wide range of information even for unregistered users. The records of the database can be freely used for nature conservation planning, dissemination and educational purposes. At the moment the Database contains 406 records; 216 of them are listed on the basic dataform, and 191 provides detailed information on the kurgans (complex dataform). For using data of the Eurasian Kurgan Database for research purposes an application should be submitted to the owner of the database describing the aims, basic methods and an approximate delineation of the data set they require. In order to draw attention on the present conservation status of the kurgans across Eurasia we aim to publish a synthesis paper using the data from the database. The planned publication aims to give a comprehensive overview on the current land cover, threatening factors present on and the cultural values associated to the kurgans of the different regions of a wide geographical range. According to the terms and conditions of the Eurasian Kurgan Database data contributors who provided at least $5 \%$ of the available data on the complex data form will be offered a coauthorship in the forthcoming publications.

We believe that compiling an open access data repository available for all interested parties both in the field of science, management and local citizens can considerably contribute to the protection of the kurgans which are essential elements of our cultural, historical and natural heritage. Therefore, we would like to encourage all interested parties to take part in the project as users or uploaders in order to enlarge our knowledge on kurgans.

\section{Acknowledgements}

The authors were supported by the NKFI KH 130338 project (BD, FB, CAT), the NKFI FK $124404(\mathrm{BD})$, and the NKFIH PD 121126 (ÁB). The project was supported by the Bolyai János Research Scholarship of the Hungarian Academy of Sciences (BD). BD was supported by the ÚNKP-18-4-DE-9 New National Excellence Programme of the Ministry of Human Capacities. IA was supported by National Science Fund (contract KП-06-H21/2).

Balázs Deák (D), https://orcid.org/0000-0001-6938-1997 Csaba Albert Tóth (D), https://orcid.org/0000-0002-0934-135X Ádám Bede (D), https://orcid.org/0000-0001-7768-439 Iva Apostolova (D), https://orcid.org/0000-0002-2701-175X Tatyana M. Bragina (D), https://orcid.org/0000-0002-5568-9082 Ferenc Báthori (D) https://orcid.org/0000-0001-5452-5257 Miklós Bán (D), https://orcid.org/0000-0002-6275-7928

\section{References}

Anthony, D. W. 2010: Horse, the Wheel and Language. How BronzeAge riders from the Eurasian steppes shaped the Modern World. Princeton University Press, Princeton-Oxford, 568 pp.

Bán, M., Végvári, Z. \& Bérces, S. 2014: An open framework for biodiversity databases. bioRxiv. 010405. doi: https://doi. org/10.1101/01040

Bastow, R. \& Leonelli, S. 2010: Sustainable digital infrastructure. EMBO Reports 11(10): 730-734. doi: https://doi.org/10.1038/ embor.2010.145

Bede, Á., Salisbury, R. B., Csathó, A. I., Czukor, P., Páll, D. G., Szilágyi, G. \& Sümegi, P. 2015: Report of the complex geoarcheological survey at the Ecse-halom kurgan in Hortobágy, Hungary. Central European Geology 58(3): 268-289. doi: https://doi. org/10.1556/24.58.2015.3.5

Bhagwat, S. \& Rutte, C. 2006: Sacred groves: potential for biodiversity management. Frontiers in Ecology and the Environment 4(10): 519-524. doi: https://doi.org/10.1890/15409295(2006)4[519:SGPFBM]2.0.CO;2

Biró, M., Bölöni, J. \& Molnár, Zs. 2018: Use of long-term data to evaluate loss and endangerment status of Natura 2000 habitats and effects of protected areas. Conservation biology 32(3): 660-671. doi: https://doi.org/10.1111/cobi.13038

Davis-Kimball, J., Murphy, E.M., Koryakova, L. \& Yablonksy, L.T. eds. 2000: Kurgans, Ritual Sites, and Settlements: Eurasian Bronze and Iron Age. BAR International Series 890. Archaeopress, Oxford, 324 pp.

Deák, B., Tóthmérész, B., Valkó, O., Sudnik-Wójcikowska, B., Bragina, T. M., Moysiyenko, I. I., Bragina, T. M., Apostolova, I., Dembicz, I., Bykov, N. I. \& Török, P. 2016a: Cultural monuments and nature conservation: The role of kurgans in maintaining steppe vegetation. Biodiversity and Conservation 25(12): 2473-2490. doi: https://doi.org/10.1007/s10531-016-1081-2

Deák, B., Valkó, O., Török, P. \& Tóthmérész, B. 2016b: Factors threatening grassland specialist plants - A multi-proxy study on the vegetation of isolated grasslands. Biological Conservation 204: 255-262. doi: https://doi.org/10.1016/j.biocon.2016.10.023

Deák, B., Tölgyesi, Cs., Kelemen, A., Bátori, Z., Gallé, R., Bragina, T. M., Abil, Y. A. \& Valkó, O. 2017: Vegetation of steppic cultural heritage sites in Kazakhstan - Effects of micro-habitats and grazing intensity. Plant Ecology and Diversity 10(5-6): 509-520. doi: https:// doi.org/10.1080/17550874.2018.1430871

Deák, B., Valkó, O., Török, P., Kelemen, A., Bede, Á., Csathó, A. I. \& Tóthmérész, B. 2018: Landscape and habitat filters jointly drive richness and abundance of specialist plants in terrestrial habitat islands. Landscape Ecology 33(7): 1117-1132. doi: https://doi.org/10.1007/ s10980-018-0660-x

Deák, B. 2019: Eurasian Kurgan Database. doi: https://doi. org/10.18426/obm.3mbbectm2bmg

Dembicz, I., Moysiyenko, I. I., Shaposhnikova, A., Vynokurov, D., Kozub, L. \& Sudnik-Wójcikowska, B. 2016: Isolation and patch size drive specialist plant species density within steppe islands: A case study of kurgans in southern Ukraine. Biodiversity and Conservation 25(12): 2289-2307. doi: https://doi.org/10.1007/s10531-016-1077-y 
Dembicz, I., Szczeparska, L., Moysiyenko, I. I. \& Wódkiewicz, M. 2018: High genetic diversity in fragmented Iris pumila L. populations in Ukrainian steppe enclaves. Basic and Applied Ecology 28: 37-47. doi: https://doi.org/10.1016/j.baae.2018.02.009

Demkin, V. A., Klepikov, V. M., Udaltsov, S. N., Demkina, T. S., Eltsov, M. V. \& Khomutova, T. E. 2014: New aspects of natural science studies of archaeological burial monuments (kurgans) in the southern Russian steppes. Journal of Archaeological Science 42: 241-249. doi: https://doi.org/10.1016/j.jas.2013.10.031

Elias, D., Hölzel, N. \& Tischew, S. 2018: Goat paddock grazing improves the conservation status of shrub-encroached dry grasslands. Tuexenia 38: 215-233. doi: https://doi.org/10.14471/2018.38.017

Erdős, L., Bátori, Z., Bede-Fazekas, Á., Biró, M., Darányi, N., Magnes, M., Pásztor, L., Sengl, P., Szitár, K., Tölgyesi, Cs. \& Kröel-Dulay, Gy. 2019: Trends in species composition and richness along a centre-toperiphery gradient in forest-steppes of the southern Carpathian Basin. Tuexenia 39: (accepted paper)

Frascaroli, F., Bhagwat, S., Guarino, R., Chiarucci, A. \& Schmid, B. 2016: Shrines in Central Italy conserve plant diversity and large trees. Ambio 45(4): 468-479. doi: https://doi.org/10.1007/s13280-015$0738-5$

Gazol, A., Tamme, R., Takkis, K., Kasari, L., Saar, L., Helm, A. \& Pärtel, M. 2012: Landscape and small-scale determinants of grassland species diversity: Direct and indirect influences. Ecography 35(10): 944-951. doi: https://doi.org/10.1111/j.1600-0587.2012.07627.x

Gimbutas, M. 2000: Das ende Alteuropas. Der Einfall von Steppennomaden aus Südrussland und die Indogermanisierung Mitteleuropas. Archaeolingua, Budapest, 135 pp.

Godó, L., Tóthmérész, B., Valkó, O., Tóth, K., Radócz, S., Kiss, R., Kelemen, A., Török, P., Švamberková, E. \& Deák, B. 2018: Ecosystem engineering by foxes is mediated by the landscape context - A case study from steppic burial mounds. Ecology and Evolution 8(14): 7044-7054. doi: https://doi.org/10.1002/ece3.4224

Gołębiowska-Tobiasz, A. 2013: Monumental polovtsian ptatues in Eastern Europe: the archaeology, conservation and protection. Versita Discipline: History, Archaeology. Versita, London, 196 pp.

Gray, S., Jordan, R., Crall, A., Newman, G., Hmelo-Silver, C., Huang, J., Novak, W., Mellor, D., Frensley, T., Prysby, M. \& Singer, A. 2016. Combining participatory modelling and citizen science to support volunteer conservation action. Biological Conservation 208: 76-86. doi: https://doi.org/10.1016/j.biocon.2016.07.037

Lisetskii, F. N., Goleusov, V. P., Moysiyenko, I. I. \& SudnikWójcikowska, B. 2014: Microzonal distribution of soils and plants along the catenas of mound structures. Contemporary Problems of Ecology 7(3): 282-293. doi: https://doi.org/10.1134/ S1995425514030111

Lisetskii, F. N., Sudnik-Wójcikowska, B. \& Moysiyenko, I. I. 2016a: Flora differentiation among local ecotypes in the transzonal study of forest-steppe and steppe mounds. Biology Bulletin 43(2): 169-176. doi: https://doi.org/10.1134/S1062359016010106

Lisetskii, F. N., Smekalova, T. N. \& Marinina, O. A. 2016b: Biogeochemical features of fallow lands in the steppe zone. Contemporary Problems of Ecology 9(3): 366-375. doi: https://doi.org/10.1134/ S1995425516030094
Löki, V., Molnár V., A., Süveges, K., Heimeier, H., Takács, A., Nagy, T., Fekete, R., Lovas-Kiss, Á., Kreutz, K. C. A. J., Sramkó, G. \& Tökölyi, J. 2019a: Predictors of conservation value of Turkish cemeteries: a case study using orchids. Landscape and Urban Planning 186: 36-44. doi: https://doi.org/10.1016/j.landurbplan.2019.02.016

Löki, V., Deák, B., Lukács, A. B., Molnár V., A. 2019b: Biodiversity potential of burial places-a review on the flora and fauna of cemeteries and churchyards. Global Ecology and Conservation, e00614. doi: https://doi.org/10.1016/j.gecco.2019.e00614

Molnár V., A., Nagy, T., Löki, V., Süveges, K., Takács, A., Bódis, J. \& Jácint, T. 2017: Turkish graveyards as refuges for orchids against tuber harvest. Ecology and Evolution 7(24): 11257-11264. doi: https://doi. org/10.1002/ece 3.3562

Molnár V., A., Mészáros, A., Csathó, A. I., Balogh, G., Takács, A., Löki, V., Lovas-Kiss, Á, Tökölyi, J., Somlyay, L. \& Bauer, N. 2018: Distribution and seed production of the rare, dry grassland specialist Sternbergia colchiciflora (Amaryllidaceae) in Pannonian cemeteries. Tuexenia 38: 371-384. doi: https://doi.org/10.14471/2018.38.015

Moysiyenko, I., Zachwatowicz, M., Sudnik-Wójcikowska, B. \& Jabłońska, E. 2014: Kurgans help to protect endangered steppe species in the Pontic grass steppe zone, Ukraine. Wulfenia 21: 83-94.

Parzinger, H. 2017: Burial mounds of Scythian elites in the Eurasian steppe: New discoveries. Journal of the British Academy 5: 331-355. doi: https://doi.org/10.5871/jba/005.331

Pető, Á. \& Barczi A. eds. (2011): Kurgan Studies. An environmental and archaeological multiproxy study of burial mounds in the Eurasian steppe zone. British Archaeological Reports International Series 2238. Archaeopress, Oxford. 350 pp.

Rowińska,A., Sudnik-Wójcikowska, B. \& Moysiyenko, I. I. 2010: Kurhany - dziedzictwo kultury w krajobrazie antropogenicznym strefy stepów i lasostepu - oczami archeologa i botanika [Kurgans from the archeologist and botanist view - cultural heritage in the stepp and forest stepp region]. Wiadomości Botaniczne 54: 7-20. [in Polish]

Sopotlieva, D., Velev, N., Tsvetkova, N., Vassilev, V. \& Apostolova, I. 2018: Ecosystem condition assessment of semi-natural grasslands outside the Natura 2000 network in Bulgaria, using vegetation data. Tuexenia 38: 385-404. doi: https://doi.org/10.14471/2018.38.012

Squires V. R., Dengler J., Hua L., Feng H. (eds.) 2018: Grasslands of the World: Diversity, Management and Conservation. CRC Taylor \& Francis Group, Boca Raton, 421 pp.

Stokstad, E. 2010: Despite progress, biodiversity declines. Science 329(5997): 1272-1273. doi: https://doi.org/10.1126/ science.329.5997.1272

Sudnik-Wójcikowska, B., Moysiyenko, I., Zachwatowicz, M. \& Jabłońska, E. 2011: The value and need for protection of kurgan flora in the anthropogenic landscape of steppe zone in Ukraine. Plant Biosystems 145(3): 638-653. doi: https://doi.org/10.1080/11263504 2011.601335

Sudnik-Wójcikowska, B. \& Moysiyenko I. I. 2014: Indicative role of the flora of kurgans in the 'Wild Field' (southern Ukraine). Monitoring Środowiska Przyrodniczego 15: 75-83.

Szabó, Sz., Novák, T. \& Elek, Z. 2012: Distance models in ecological network management: A case study of patch connectivity in a grassland network. Journal for Nature Conservation 20(5): 293-300. doi: https://doi.org/10.1016/j.jnc.2012.06.002 
Szabó, A. \& Ruprecht, E. 2018: Restoration possibilities of dry grasslands afforested by pine: the role of seed bank and remnant vegetation. Tuexenia 38: 405-418. doi: https:/doi. org/10.14471/2018.38.013

Szilágyi, G., Sümegi, P., Molnár, D. \& Sávai, S. 2013: Mollusc-based paleoecological investigations of the Late Copper - Early Bronze Age earth mounds (kurgans) on the Great Hungarian Plain. Open Geosciences 5: 465-479. doi: https://doi.org/10.2478/s13533-0120153-4

Tóth, Cs. A., Pethe, M. \& Hatházi, Á. 2014: The application of earth science-based analyses on a twin-kurgan in Northern Hungary. Carpathian Journal of Earth and Environmental Sciences 9(1): 19-20.

Tóth, Cs. A., Rákóczi, A. \& Tóth, S. 2018: Protection of the state of prehistoric mounds in Hungary: law as a conservation measure. Conservation and Management of Archaeological Sites 20(3): 113-142. doi: https://doi.org/10.1080/13505033.2018.1486125

Valkó, O., Zmihorski, M., Biurrun, I., Loos, J., Labadessa, R., Venn, S. 2016: Ecology and conservation of steppes and semi-natural grasslands. Hacquetia 15: 5-14.

Valkó, O., Venn, S., Zmihorski, M., Biurrun, I., Labadessa, R., Loos, J. 2018a: The challenge of abandonment for the sustainable management of Palaearctic natural and semi-natural grasslands. Hacquetia 17: 5-16. doi: DOI: 10.1515/hacq-2017-0018

Valkó, O., Tóth, K., Kelemen, A., Miglécz, T., Sonkoly, J., Tóthmérész, B., Török, P. \& Deák, B. 2018b: Cultural heritage and biodiversity conservation - Plant introduction and practical restoration on ancient burial mounds. Nature Conservation 24: 65-80. doi: https://doi. org/10.3897/natureconservation.24.20019

Verschuuren, B., Wild, R., McNeeley, J. \& Oviedo, G. (eds.) 2010: Sacred Natural Sites: Conserving Nature and Culture. Earthscan, London, $310 \mathrm{pp}$.

Wódkiewicz, M., Dembicz, I. \& Moysiyenko, I. I. 2016: The value of small habitat islands for the conservation of genetic variability in a steppe grass species. Acta Oecologica 76: 22-30. doi: https://doi. org/10.1016/j.actao.2016.08.001 